\title{
KONTRIBUSI PEMBERIAN MENU SIKLUS 3 HARI TERHADAP ASUPAN GIZI ATLET PENCAK SILAT DI ASRAMA
}

\section{CONTRIBUTION OF GIVING A 3-DAY CYCLE MENU ON NUTRIENT INTAKE OF PENCAK SILAT ATHLETES IN DORMITORY}

\author{
Yuni Afriani $^{1 *}$, Sri Kadaryati ${ }^{1}$, Umi Mahmudah ${ }^{1}$ \\ ${ }^{1}$ Pogram Studi Gizi Program Sarjana, Fakultas Ilmu Kesehatan, \\ Universitas Respati Yogyakarta, \\ Jl. Raya Tajem Km 1,5 Maguwoharjo, Depok, Sleman, Yogyakarta. \\ *email: yuni.afriani89@gmail.com
}

\begin{abstract}
Food regulation and nutrient intake based on the calculation of needs have a positive impact on performance. Organizing food for athletes is an important thing to be considered in each phase, namely training, competing, and recovery phases. This study aims to determine the contribution of the 3-day cycle menu to the nutritional intake of athletes of pencak silat in dormitories. This research was a quasi experimental study using a pre-post design. Food intake was seen based on energy, carbohydrates, protein, and fat. Before the intervention, the subjects received food according to the menu given in the dormitory. The intervention given was the provision of a 3-day cycle menu, which was adjusted to the needs and eating habits of the athletes. The research was conducted in July-August 2016 at the Yogyakarta Pencak Silat Athlete Dormitory. Data were analyzed using statistical software with paired t-test. The results showed that there was a significant difference in energy, protein and fat intake before and after giving the 3-day cycle menu to pencak silat athletes in dormitories $(p<0.05)$. However, there was no significant difference in carbohydrate intake before and after the intervention ( $p>0.05$ ). Giving a 3-day cycle menu could contribute to increase the nutritional intake of pencak silat athletes.
\end{abstract}

Keywords: food service management, nutritional intake, athletes, pencak silat

\begin{abstract}
ABSTRAK
Pengaturan makanan dan asupan zat gizi yang sesuai dengan kebutuhan akan berdampak positif pada performa dan prestasi atlet agar optimal. Penyelenggaraan makanan pada atlet merupakan hal penting yang perlu diperhatikan di setiap fase yaitu fase latihan, bertanding, dan recovery. Penelitian bertujuan untuk mengetahui kontribusi pemberian menu siklus 3 hari terhadap asupan zat gizi atlet pencak silat di Asrama. Penelitian ini merupakan penelitian quasi eksperimental dengan menggunakan rancangan pre-post. Asupan makan dilihat berdasarkan energi, karbohidrat, protein, dan lemak. Sebelum intervensi, responden mendapatkan makanan sesuai dengan menu yang diberikan di asrama. Intervensi yang diberikan adalah pemberian makanan dengan menu siklus 3 hari, yang telah disesuaikan dengan kebutuhan dan kebiasaan makan atlet. Penelitian dilakukan pada bulan Juli-Agustus 2016 di Asrama Atlet Pencak Silat Yogyakarta. Analisis data menggunakan software statistik dengan uji paired t-test. Hasil penelitian menunjukkan bahwa ada perbedaan yang signifikan asupan energi, protein dan lemak antara sebelum dan sesudah pemberian menu siklus 3 hari pada atlet pencak silat di asrama $(\mathrm{p}<0,05)$. Namun, tidak terdapat perbedaan yang signifikan pada asupan karbohidrat antara sebelum dan setelah intervensi $(p>0,05)$. Pemberian menu siklus 3 hari dapat memberikan kontribusi peningkatan asupan zat gizi atlet pencak silat.
\end{abstract}

Kata kunci: penyelenggaraan makanan, asupan zat gizi, atlet, pencak silat 


\section{PENDAHULUAN}

Pencak silat merupakan bela diri tradisional Indonesia yang sudah diakui dunia dan telah dilakukan kompetisi di tingkat nasional maupun internasional. Pada olahraga pencak silat, kondisi fisik menjadi kunci keberhasilan pada saat berkompetisi (Hariono, 2006). Latihan fisik merupakan cara untuk memperbaiki atau mempertahankan kesegaran jasmani pada atlet (Wulandari, 2004). Pengaturan makanan sesuai dengan kebutuhan gizi akan memberikan pengaruh yang positif terhadap peningkatan performa serta prestasi atlet (Departemen Kesehatan RI, 2007).

Beberapa penelitian menunjukkan kecukupan gizi atlet belum terpenuhi. Hasil penelitian menunjukkan bahwa kecukupan energi berdasarkan kuesioner food recall 24 jam pada siswa di SMAN 1 Nganjuk yang mengikuti ekstrakurikuler pencak silat masuk dalam kategori kurang, tingkat kecukupan protein masuk dalam kategori kurang, tingkat kecukupan lemak masuk dalam kategori kurang, dan tingkat kecukupan karbohidrat masuk dalam kategori kurang (Cahyono \& Nurhayati, 2014). Ulfa et al. (2017), menambahkan bahwa konsumsi energi pada atlet masuk dalam kategori kurang dan defisit, sedangkan konsumsi protein masuk dalam kategori defisit. Kebugaran jasmani pada siswa tidak memiliki perbedaan yang bermakna antara tingkat konsumsi gizi, status gizi, dan kebugaran jasmani baik pada siswa yang mengikuti ekstrakurikuler pencak silat dan futsal. Namun, ada perbedaan yang signifikan untuk tingkat aktivitas fisik pada siswa yang mengikuti ekstrakurikuler pencak silat dan futsal.

Persentase dehidrasi pada atlet pencak silat di UNY berdasarkan berat jenis urin $85 \%$ dan warna urin $52,5 \%$. Rata-rata asupan cairan minuman pada atlet pencak silat UNY sebesar $2.051,20 \mathrm{ml}$ per hari. Jenis minuman yang paling banyak dikonsumsi setiap harinya oleh atlet pencak silat UNY adalah air mineral dengan volume $<1500 \mathrm{ml}$ (55\%) dan penyegar (95\%). Namun, tidak terdapat hubungan yang signifikan antara jumlah asupan cairan dan jenis minuman dengan status hidrasi pada atlet pencak silat $(p>0,05)$. Pada saat berolahraga, atlet dianjurkan untuk mengonsumsi cairan (minuman olahraga) sebelum (400-600 ml), selama olahraga (150-350 ml setiap 15 hingga 20 menit) dan sesudah olahraga menyesuaikan penurunan berat badan (Rachmawati et al., 2014). 
Makanan dan minuman yang dikonsumsi menentukan penampilan seorang atlet dalam berbagai hal. Pada tingkat latihan dasar, gizi yang baik penting dalam mempertahankan kesehatan optimal yang membuat atlet mampu berlatih dan berkompetisi dengan baik. Kebutuhan energi merupakan hal yang diutamakan seorang atlet. Hal ini diperlukan untuk menjaga massa jaringan, status kekebalan tubuh dan fungsi reproduksi serta performa atlet secara optimum (Kandarina, 2007). Atlet dengan tingkat energi yang cukup akan lebih mampu menerima beban kerja pada saat bertanding dibandingkan dengan atlet dengan tingkat kecukupan energi kurang (Wulandari, 2004).

Asupan protein yang sesuai dengan kebutuhan juga dibutuhkan bagi seorang atlet. Sumber protein hewani dan nabati yang dikonsumsi dalam jumlah cukup dapat menunjang performa (Departemen Kesehatan RI, 2007). Pola makan pada atlet pencak silat selama Pelatda di Bali memiliki kecenderungan mengonsumsi daging, suplemen $\mathrm{Fe}$ dan vitamin $\mathrm{C}$ secara berlebihan (Widiastuti et al., 2009). Agustin et al. (2018) menyebutkan bahwa sebagian besar atlet pencak silat di Pembinaan Atlet Berbakat (PAB) Yogyakarta mempunyai asupan protein yang belum sesuai dengan kebutuhan. Ditambah pula pada penelitian Yanti et al., (2018), pola konsumsi sayur dan buah pada atlet pencak silat di Bayad Tegallalang Gianyar sebagian besar masuk dalam kategori kurang dan porsinya belum sesuai anjuran yang seharusnya.

Atlet yang memiliki tingkat kegiatan aktivitas fisik yang tinggi membutuhkan konsumsi zat gizi yang tepat komposisinya agar ketersediaan sumber energi di dalam tubuh dapat tetap terjaga baik untuk menjalankan aktivitas sehari-hari maupun saat akan menjalani program latihan atau saat akan bertanding (Irawan, 2007). Penyediaan makanan dalam pemusatan latihan atlet merupakan bagian yang harus ditangani secara benar, baik dari segi kualitas, kuantitas termasuk segi keamanan makanan (Woro, 2005). Beberapa titik kritis yang banyak ditemui pada atlet adalah makan dalam jumlah yang tidak cukup, tidak mengetahui jumlah makanan yang harus dikonsumsi, konsumsi energi kurang, memilih makanan secara tidak seimbang dan benar, tidak mengetahui tentang gizi, dan asupan energi untuk kompetisi (Purba, 2007). Asupan gizi yang tepat sangat penting bagi atlet pencak silat dalam pencapaian prestasinya. Perlunya ketepatan dalam mengonsumsi makanan, minuman serta tambahan suplemen dalam perbaikan 
kondisi tubuh dan pengoptimalan performa atlet baik pada saat latihan maupun saat bertanding (Paiman, 2010).

Hasil penelitian Kuswari et al. (2019) menyebutkan bahwa asupan energi, karbohidrat, vitamin $\mathrm{C}$ dan asupan Fe memiliki hubungan yang signifikan dengan performa pada atlet Dyva Taekwondo Centre Cibinong. Namun, asupan protein, lemak dan vitamin B1 tidak memiliki hubungan yang signifikan. Penelitian lain menyebutkan bahwa sebagian besar atlet memiliki status gizi normal sebanyak $95 \%$ dan status gizi gemuk $5 \%$. Namun, sebagian besar atlet belum memenuhi asupan energi dan protein yang sesuai dengan kebutuhan. Performa atlet yang baik pada atlet yang mengonsumsi energi sesuai dengan kebutuhan sebesar 3,7\%. Atlet yang memiliki performa yang kurang diketahui asupanya kurang dari kebutuhan yang seharusnya. Selain itu, atlet yang asupan proteinya sesuai memiliki performa yang baik sebanyak $11,1 \%$, dan atlet yang asupan proteinya kurang memiliki performa yang kurang pula (Chandradewi \& Irianto, 2017).

Hal ini menunjukkan bahwa sistem penyelenggaraan makanan yang baik diperlukan untuk mendukung peningkatan kualitas dan performa atlet. Oleh karena itu, perlu adanya sistem penyelenggaraan makan untuk atlet. Pengelolaan makanan dikelola oleh tim gizi, yang bertanggung jawab secara keseluruhan terhadap penyediaan makan atlet yang menyangkut menu makanan, kualitas makanan, kuantitas makanan dan pengawas bahan mentah, pengelolaan serta penyajiannya, yang disesuaikan dengan keahlian masing-masing anggota tim (Woro, 2005).

Perencanaan menu merupakan rangkaian kegiatan untuk menyusun hidangan dalam berbagai variasi untuk memuaskan konsumen (Kemenkes RI, 2014). Perencanaan menu bagian penting dalam penyelenggaraan makanan di institusi. Tujuan perencanaan menu yaitu menyusun pedoman dalam kegiatan pengolahan makanan, mengatur variasi dan kombinasi hidangan, menyesuaikan anggaran yang tersedia, serta menghemat penggunaan waktu dan tenaga. Menu yang dihidangkan juga menjadi media edukasi secara tidak langsung kepada konsumen (Rotua \& Siregar, 2015).

Penyelenggaraan makanan di Asrama Yogyakarta sebelumnya dilakukan dengan sistem kerjasama (outsourcing) dengan katering. Berdasarkan pengamatan di lapangan, besar porsi hidangan yang disajikan belum sesuai dengan kecukupan gizi atlet. Hasil wawancana dengan 
pengelola asrama menunjukkan belum adanya penggalian data kebutuhan gizi atlet yang digunakan sebagai dasar penyediaan hidangan. Oleh karena itu, peneliti menerapkan pengaturan makanan pada atlet pencak silat yang tinggal di Asrama Yogyakarta dengan memperbaiki penyelenggaraan makanan di asrama melalui penyusunan menu siklus 3 hari dengan penyesuaian pada kecukupan gizi atlet dari cabang olah raga pencak silat. Pemilihan bahan makanan disesuaikan dengan pola makan atlet berdasarkan penggalian data menggunakan semi quantitative-food frequency (SQ-FFQ). Pentingnya asupan yang sesuai dengan kebutuhan dan pentingnya pengaturan makanan pada atlet pencak silat yang tinggal di Asrama Yogyakarta sehingga perlunya diterapkan pemberian menu siklus 3 hari dengan melihat pengaruhnya terhadap asupan makan atlet.

\section{METODE}

\section{Desain, tempat, dan waktu}

Penelitian ini merupakan penelitian quasi eksperimental dengan menggunakan rancangan pre-post. Pre-eliminary study dilakukan untuk menghitung kecukupan gizi atlet. Asupan makan dilihat berdasarkan energi, karbohidrat, protein, dan lemak.
Sebelum intervensi, subjek mendapatkan makanan sesuai dengan menu dan sistem penyelenggaraan makanan yang diberikan di asrama. Intervensi yang diberikan adalah menu siklus 3 hari, yang telah disesuaikan dengan kecukupan dan kebiasaan makan atlet. Penelitian dilakukan pada Juli-Agustus 2016 di Asrama Atlet Pencak Silat Yogyakarta yang memiliki atlet pencak silat yang sudah terlatih dan aktif mengikuti kompetisi.

\section{Jumlah dan cara pengambilan subjek/alat dan bahan penelitian}

Responden penelitian ini adalah semua atlet pencak silat yang tinggal di Asrama Atlet pencak Silat Yogyakarta dan tidak sedang mengikuti pertandingan di luar daerah, yang berjumlah 5 orang atlet yang terdiri atas 3 orang atlet perempuan dan 2 orang atlet laki-laki. Pengambilan responden menggunakan purposive sampling dengan memperhatikan kriteria inklusi dan eksklusi. Kriteria inklusi responden yaitu bersedia menjadi responden penelitian dengan menandatangani informed consent; berada di lokasi penelitian selama penelitian berlangsung. Kriteria eksklusinya yaitu responden menderita cidera atau sedang dalam perawatan dokter. 
Jenis dan cara pengumpulan data/langkahlangkah penelitian

Pre-eliminary Study. Kebutuhan

masing-masing atlet diperoleh berdasarkan perhitungan Harris Benedict, kebutuhan untuk aktivitas fisik dan olah raga. Data tinggi badan dan berat badan atlet yang digunakan untuk menghitung kebutuhan kalori, diperoleh dari pengukuran langsung menggunakan alat yang telah terkalibrasi. Data kebutuhan energi, karbohidrat, lemak, dan protein semua atlet kemudian dirata-rata sehingga diperoleh data kecukupannya. Data kebiasaan makan atlet diperoleh berdasarkan form food frequency questionare.

Pre-Intervensi. Data asupan makan sebelum intervensi diperoleh dengan recall 24 jam. Metode ini dipilih karena penyajian makanan di asrama menggunakan sistem prasmanan. Hasil recall 24 jam kemudian dikonversi menjadi asupan energi, karbohidrat, lemak, dan protein, berdasarkan perhitungan menggunakan daftar Bahan Makanan Penukar (BMP).

Intervensi. Atlet diberikan makanan selama 3 hari, sesuai dengan menu siklus. Menu siklus setiap hari terdiri dari 3 kali makan dan 2 kali selingan, yang sudah diporsikan pada setiap waktu makan. Menu siklus telah disesuaikan dengan kecukupan gizi dan kebiasaan makan atlet. Penyusunan menu menggunakan alat bantu daftar Bahan Makanan Penukar (BMP), yang merupakan daftar bahan makanan berdasarkan kandungan energi, karbohidrat, protein, dan lemak pada setiap bahan hidangan.

Post-Intervensi. Data asupan makan setelah intervensi diperoleh berdasarkan pengamatan visual sisa makanan (untuk menu siklus yang disajikan) dikombinasikan dengan recall 24 jam (untuk makanan di luar asrama). Hasil pengamatan visual sisa makanan dikonversi menjadi data asupan berdasarkan kandungan energi, karbohidrat, protein, dan lemak pada setiap hidangan. Hasil recall 24 jam kemudian dikonversi menjadi asupan energi, karbohidrat, lemak, dan protein, berdasarkan perhitungan menggunakan daftar Bahan Makanan Penukar (BMP).

\section{Analisis data}

Pengolahan dan analisis data dijelaskan berurutan dalam bentuk paragraf. Uji normalitas data menggunakan uji saphirowilk untuk mengetahui sebaran data. Perbedaan asupan antara pre dan post intervensi dianalisis menggunakan paired $t$ test dengan pertimbangan perbedaan signifikan adalah $p<0,05$. 


\section{HASIL DAN PEMBAHASAN}

Responden penelitian ini berjumlah lima orang atlet pencak silat yang tinggal di Asrama Atlet Pencak Silat di Yogyakarta. Karakteristik responden dalam penelitian ini adalah usia, berat badan, tinggi badan, dan

Tabel 1. Karakteristik Subjek

\begin{tabular}{ccc}
\hline Karakteristik & n (\%) & mean \pm SD \\
\hline Usia $(\operatorname{tahun})$ & $5(100 \%)$ & $17.20 \pm 0.837$ \\
Berat Badan $(\mathrm{kg})$ & $5(100 \%)$ & $55.72 \pm 9.25$ \\
Tinggi Badan $(\mathrm{cm})$ & $5(100 \%)$ & $163.78 \pm 4.57$ \\
IMT $\left(\mathrm{kg} / \mathrm{m}^{2}\right)$ & $5(100 \%)$ & $19,98(18,47-24,54)^{*}$ \\
\hline
\end{tabular}

Keterangan:

indeks massa tubuh (BMI) yang dapat dilihat pada Tabel 1. Diketahui bahwa ratarata usia atlet pencak silat adalah 18 tahun dengan status gizi berdasarkan Indeks Massa Tubuh semua atlet dalam kategori normal.

*median (min-maks)

Atlet pencak silat ini merupakan siswa SMA di beberapa sekolah setingkat Sekolah Menengah Atas (SMA dan sederajat) di Yogyakarta dengan rutinitas sehari-hari yaitu berangkat sekolah pada pukul 06.30 WIB dan pulang ke asrama pada pukul 14.00 WIB. Sementara, para atlet berlatih pada pukul 15.30 WIB. Jadwal kegiatan ini sangat mempengaruhi kebiasaan makan para atlet.

Penyelenggaraan makanan pada atlet merupakan salah satu bagian vital yang dapat menunjang performa. Penyelenggaraan makanan bagi atlet sangat dibutuhkan untuk menyiapkan makanan terbaik bagi atlet tentunya dengan penyesuaian yaitu biaya makanan yang sudah dianggarkan, perhitungan kebutuhan masing-masing atlet, kualitas makanan, aman, dapat diterima oleh atlet sehingga dapat meningkatkan performa. Selain itu, penyelenggaraan makanan pada atlet harus disesuaikan dengan cabang olahraga, lama berolahraga/ bertanding, intensitas latihan, agar sesuai dengan kebutuhan masingmasing atlet. Oleh karena itu, makanan yang sesuai dengan kebutuhan atlet menjadi hal yang penting untuk berkontribusi dalam peningkatan performa dan prestasi atlet (Kementerian Kesehatan RI, 2014). Berdasarkan Tabel 2. diketahui bahwa ratarata asupan atlet meningkat setelah diberikan intervensi berupa pemberian menu siklus 3 hari dan dibandingkan dengan ratarata kebutuhan atlet. 
Tabel 2. Pemenuhan Asupan Atlet Pada Pemberian Menu Siklus 3 Hari

\begin{tabular}{lccc}
\hline \multicolumn{1}{c}{ Zat Gizi } & Rata-rata Asupan & Rata-rata Kebutuhan & \% Pemenuhan \\
\hline Energi (kkal) & $2257.48 \pm 102.63$ & $3065.57 \pm 163.69$ & $73.63 \%$ \\
Protein (gram) & $84.38 \pm 6.40$ & $114.95 \pm 6.13$ & $73.40 \%$ \\
Lemak (gram) & $80.72 \pm 16.28$ & $85.15 \pm 4.54$ & $94.79 \%$ \\
Karbohidrat (gram) & $301.04 \pm 18.20$ & $306.56 \pm 16.37$ & $98.20 \%$ \\
\hline
\end{tabular}

Pemberian intervensi meningkatkan pemenuhan energi atlet, meskipun pemenuhan kebutuhan ini masih tergolong dalam kategori asupan kurang (73.63\%). Asupan protein atlet memberikan kontribusi pemenuhan kebutuhan sebesar 73,40\% (asupan kurang). Asupan lemak atlet memberikan kontribusi pemenuhan asupan lemak atlet sebesar 94.79\% (asupan baik), sedangkan asupan karbohidrat memberikan kontribusi pemenuhan sebesar $98.20 \%$ (asupan baik).

Asupan zat gizi sangat penting untuk menunjang performa pada atlet saat berlatih dan bertanding. Kebutuhan kalori menjadi hal yang penting dalam mendukung kinerja fisik, daya tahan tubuh, fungsi fisiologis dan penampilan yang optimal (Kandarina, 2007). Asupan energi atlet yang sesuai dengan kebutuhan memiliki kemampuan fisik yang lebih baik saat berkompetisi (Wulandari, 2004).

Asupan protein sangat dibutuhkan seorang atlet bagi cabang olahraga dengan kekuatan atau power. Protein berperan penting untuk membantu penbentukan serabut dan massa otot. Asupan protein yang cukup dapat membantu peningkatan performa pada atlet (Kemenkes 2014). Sumber protein yang dikonsumsi baik dari sumber nabati maupun hewani sangat penting dikonsumsi dalam jumlah yang cukup (Departemen Kesehatan RI, 2007). Hasil penelitian menunjukkan bahwa masih banyak atlet yang belum mengonsumsi protein sesuai kebutuhan (Agustin et al., 2018).

Makanan yang dikonsumsi atlet pencak silat di Asrama Yogyakarta merupakan makanan yang diselenggarakan dengan sistem outsourcing dari rekanan katering. Berdasarkan hasil observasi dan wawancara dengan pengelola asrama diketahui bahwa porsi makanan yang disajikan belum mempertimbangkan kebutuhan harian atlet. Sehingga, perlunya penerapan pengaturan makanan pada atlet pencak silat dengan mempertimbangkan kebutuhan gizi masing-masing atlet. Penerapan menu siklus 3 hari merupakan salah satu metode penyelenggaraan makanan 
yang bisa diterapkan untuk melihat pemenuhan asupan makan atlet sesuai dengan kebutuhan. Pemilihan bahan makanan dalam penyusunan menu yang diterapkan merupakan hasil wawancara dengan menggunakan kuesioner semi quantitative food frequency (SQFFQ).

Tabel 3. Perbedaan Pemenuhan Asupan Atlet Pre-Post Pemberian Menu Siklus 3 Hari

\begin{tabular}{lccc}
\hline \multicolumn{1}{c}{ Zat Gizi } & Pre-Intervensi & Post Intervensi & $\boldsymbol{P}$ \\
\hline Energi (kkal) & $1583,33 \pm 418,48$ & $2257,48 \pm 102,63$ & $0,009^{*}$ \\
Protein (gram) & $63,20 \pm 15,28$ & $84,38 \pm 6,40$ & $0,009^{*}$ \\
Lemak (gram) & $60,38 \pm 15,57$ & $80,72 \pm 16,28$ & $0,025^{*}$ \\
Karbohidrat (gram) & $236,69 \pm 74,16$ & $301,04 \pm 18,20$ & 0,077 \\
\hline
\end{tabular}

Keterangan: *) Signifikan $(\mathrm{p}<0,05)$

Penerapan menu siklus 3 hari yang dilakukan adalah dengan memberikan menu makanan kepada atlet pencak silat di Asrama Yogyakarta dengan komponen makan utama 3 kali dengan 2 kali selingan yang diberikan selama 3 hari berturut-turut. Menu siklus yang diberikan sudah menyesuaikan kebutuhan harian dan kebiasaan makan atlet dengan menggunakan intrumen berupa Bahan Makanan Penukar (BMP).

Berdasarkan Tabel 3. diketahui bahwa asupan energi, protein, dan lemak pada atlet pencak silat memiliki perbedaan yang signifikan dengan adanya peningkatan asupan antara sebelum dan setelah pemberian menu siklus 3 hari $(\mathrm{p}<0,05)$, sedangkan asupan karbohidrat atlet mengalami peningkatan setelah pemberian menu siklus 3 hari namun tidak memiliki perbedaaan yang signifikan ( $\mathrm{p}>0,05)$.

Hal ini sejalan dengan hasil penelitian Afriani et al. (2017) yang menyebutkan bahwa daya terima atlet pada pemberian menu siklus 3 hari tergolong baik terhadap lauk hewani, lauk nabati, sayur dan buah dibandingkan dengan nasi. Daya terima pada lauk hewani termasuk dalam kategori $100 \%$ baik, pada pemberian lauk nabati $80 \%$ atlet memiliki daya terima yang baik, pada pemberian sayur $100 \%$ atlet memiliki daya terima yang baik, dan pada pemberian buah $100 \%$ atlet memiliki daya terima yang baik, namun daya terima makanan pokok sebesar $20 \%$.

Rata-rata asupan atlet jika dibandingkan dengan kebutuhan sudah tercukupi, namun masih kurang pada pemenuhan energi dan protein $(<80 \%)$, 
sedangkan pemenuhan lemak dan karbohidrat sudah baik (> 80\%) (Departemen Kesehatan, 2007). Hal ini berkaitan dengan pola aktivitas dan latihan atlet yang dilaksanakan pada pukul 15.30 WIB sementara atlet baru pulang sekolah sekitar pukul 14.00 WIB. Atlet lebih memilih untuk istirahat (tidur siang) dibandingkan untuk makan. Namun, jika dibandingkan dengan makanan yang disediakan oleh asrama, atlet mengalami peningkatan asupan pada saat pemberian menú siklus 3 hari dan terbukti secara statistik mengalami peningkatan yang signifikan $(\mathrm{p}<0,05)$, kecuali pada sumber karbohidrat.

Hal ini disebabkan banyak atlet yang memilih mengonsumsi makanan di luar asrama yaitu snack berkarbohidrat di sekolah dan pada malam hari sehingga daya terima nasi yang diberikan di asrama saat pemberian menu siklus 3 hari saat waktu makan siang sebelum latihan cenderung rendah. Daya terima terhadap makanan sumber karbohidrat yang rendah dikarenakan jarak antara makan siang dengan latihan terlalu dekat yaitu hanya 1,5 jam. Jenis makanan yang sering dikonsumsi atlet di luar makanan asrama antara lain pisang goreng, pempek, donut salju, sate ayam, ayam geprek (Afriani et al., 2016).
Hasil penelitian yang dilakukan pada atlet pencak silat PPLP DKI Jakarta dan Ragunan pada masa kompetisi menunjukkan bahwa sebagian besar atlet mengonsumsi makanan dan minuman manis sebanyak $84,61 \%$. Selain itu, sebanyak $83,33 \%$ atlet menyukai makanan yang mengandung lemak dan santan. Dari hasil penelitian tersebut juga tergambarkan bahwa 72,54\% atlet memiliki kedisiplinan yang rendah terkait upaya untuk menjaga berat badan. Hal ini dikarenakan pengetahuan pelatih yang kurang tentang aplikasi ilmu Gizi dan Fisiologi Olahraga serta sebanyak 23,5\% pelatih tidak terlalu memperhatikan status gizi salah satunya berat badan dari atlet (Faizal \& Hadi, 2019).

Pemberian menu siklus 3 hari pada penelitian ini, lebih dapat diterima pada atlet perempuan dibandingkan dengan atlet lakilaki. Hal ini sejalan dengan penelitian Sutyawan \& Setiawan (2013) yang menyebutkan bahwa kontribusi asupan energi dan zat gizi pada menu asrama lebih besar pada siswa perempuan dibandingkan laki-laki. Namun, asupan makanan dari luar asrama berkontribusi lebih besar pada siswa laki-laki dibandingkan dengan perempuan. Asupan energi, protein, dan vitamin $\mathrm{C}$ pada siswa laki-laki kurang dari kecukupan, sedangkan asupan energi, protein, dan 
vitamin C pada perempuan cenderung lebuh baik dibandingkan siswa laki-laki.

Asupan makanan, minuman, dan suplemen yang tepat sesuai dengan fase latihan atau bertanding sangat penting dikonsumsi oleh atlet untuk menunjang kondisi fisik, dan pengoptimalan performa saat latihan atau bertanding (Paiman, 2010). Berdasarkan hasil wawancara dengan atlet, diketahui bahwa pola latihan yang dilakukan atlet adalah setiap hari Senin-Sabtu, libur di hari Sabtu sore dan Ahad dengan durasi setiap kali latihan adalah 2,5 jam yang dibagi menjadi pagi dan sore hari. Oleh karena itu, diperlukan pengaturan menu makanan yang sesuai dengan waktu latihan atlet. Menurut Kementerian Kesehatan RI (2014), pengaturan asupan gizi disesuaikan dengan tahapan aktivitas olahraga, saat sebelum latihan/ bertanding, pada saat latihan/ bertanding dan recovery. Adapun pembagian waktu makan sebelum latihan adalah mengonsumsi makanan lengkap 3-4 jam sebelum latihan/ bertanding, mengonsumsi makanan ringan 2-3 jam sebelum latihan/ bertanding, mengonsumsi makanan cair berupa jus buah 1-2 jam sebelum latihan/ bertanding, mengonsumsi minuman cair selama 60-30 menit sebelum latihan/ bertanding.
Penyelenggaraan makan atlet di Asrama Atlet Pencak Silat Yogyakarta menggunakan rekanan katering dengan sistem prasmanan dengan belum adanya pertimbangan perhitungan kebutuhan harian atlet. Pemberian menu siklus 3 hari yang diberikan harapannya dapat memberikan pemenuhan sesuai dengan kebutuhan masing-masing atlet sesuai dengan aktivitas olahraga dengan sistem pemorsian dan monitoring evaluasi terkait daya terima dan kesesuaian menu yang diberikan dengan kebutuhan harian atlet. Menu siklus 3 hari setidaknya dapat memberikan gambaran kontribusi menu yang diberikan terhadap kebutuhan atlet.

Sejalan dengan hasil penelitian Nurdianty et al. (2012) yang menjelaskan bahwa beberapa asrama sudah memiliki katering yang menyiapkan makanan untuk atlet. Namun, sistem penyelengaraan makanan di PPLP Sudiang Sulawesi masih terdapat beberapa kekurangan karena tidak terdapat perhitungan kebutuhan gizi atlet sesuai masing-masing individu, belum mempunyai checklist penerimaan dan penimbangan pada bahan makanan, dan tidak adanya monitoring dan evaluasi. Terdapat asrama atlet yang sudah mulai menerapkan sistem penyelenggaraan makanan salah satunya adalah pada atlet 
sepak bola Persiba Bantul Yogyakarta. Namun, perhitungan kebutuhan bukan dihitung menurut kebutuhan secara individual. Selain itu, diperlukan pengaturan secara khusus mengikuti periodisasi latihan yaitu saat fase latihan, saat latihan atau pertandingan, dan fase pemulihan (Hasbullah et al., 2017).

Hal ini menjadi sangat penting untuk diperhatikan karena asupan atlet yang sesuai dengan kebutuhan akan berkorelasi positif dengan stamina. Atlet dengan asupan energinya tidak sesuai kebutuhan memiliki stamina yang kurang sebesar $92,3 \%$. Atlet yang asupan proteinnya kurang sesuai juga memiliki kecenderungan stamina yang kurang (Chandradewi dan Irianto, 2017). Kuswari et al. (2019) menambahkan bahwa asupan energi, karbohidrat, zat besi, vitamin C berpengaruh secara signifikan terhadap stamina pada atlet Dyva Taekwondo Centre Cibinong.

Sistem penyelenggaraan makanan penting untuk menunjang keberhasilan atlet. Menurut Irianto (2007), faktor-faktor yang penting juga diperhatikan untuk menyajikan menu makanan antara lain makanan berasal dari bahan makanan yang bisa dikonsumsi, frekuensi makanan utama dan selingan sesuai dengan standar, sesuai dengan kapasitas lambung, menarik, sesuai selera, terpenuhi standar gizinya, variatif, halal, mempertimbangkan kebiasaan makanan yang sering dikonsumsi, Pentingnya perbaikan manajeman gizi pada atlet meliputi pengaturan makan atlet mulai dari pembinaan awal, sebelum bertanding, pada saat bertanding, dan recovery. Pengaturan pola makan atlet seharusnya menyesuaikan dengan prinsip gizi seimbang termasuk dalam penggunaan suplemen baik dari sumber vitamin maupun mineral. Perlunya melibatkan ahli gizi sebagai pihak yang dapat memberikan arahan terkait pengaturan manajemen penyelenggaraan makanan pada atlet sesuai dengan kebutuhan masingmasing individu. Selain itu, pendidikan gizi juga diperlukan bagi atlet dan pelatih agar lebih mengetahui bagaimana penerapan gizi yang tepat untuk menunjang performa (Arsani et al., 2014).

\section{KESIMPULAN}

Pemberian menu siklus 3 hari memberikan kontribusi terhadap peningkatan pemenuhan kebutuhan energi, protein, lemak, dan karbohidrat pada atlet pencak silat di Asrama Yogyakarta. Ada perbedaan asupan energi, lemak dan protein secara signifikan antara pemberian menu siklus 3 hari dan menu sebelumnya di asrama. Namun, perbedaan asupan 
karbohidrat tidak menunjukkan adanya perbedaan yang signifikan secara statistik

Perlunya pemberian edukasi kepada atlet, pelatih, dan pengelola asrama atlet tentang pengaturan dan pemilihan makanan yang tepat serta sesuai dengan kebutuhan, cabang olahraga, dan periodesasi latihan agar menunjang keberhasilan dan prestasi atlet saat bertanding. Sebaiknya dipertimbangkan pengaturan jadwal makan sesuai dengan kegiatan sehari-hari para atlet, untuk memaksimalkan asupan makan dari pengaturan menu.

\section{UCAPAN TERIMA KASIH}

Ucapan terima kasih diberikan kepada Pusat Penelitian dan Pengabdian Masyarakat Universitas Respati Yogyakarta yang telah memberikan dukungan dana dalam menyelesaikan penelitian ini, serta kepada para atlet dan pengurus Asrama Yogyakarta atas kerjasama yang dilakukan selama penelitian.

\section{DAFTAR PUSTAKA}

Afriani, Y., Kadaryati, S., Mahmudah, U. (2017). Daya Terima Atlet Pencak Silat pada Pemberian Menu Siklus 3 Hari di PPLP Yogyakarta. Medika
Respati Suplemen Vol 12. https://doi.org/10.35842/mr.v0i0.147

Afriani, Y., Kadaryati, S., (2016). Pengaruh Pemberian Menu Siklus 3 Hari terhadap Tingkat Konsumsi Energi, Karbohidrat, Protein, Lemak, Kepuasan dan Daya Terima pada Atlet Di PPLP Yogyakarta. Laporan Penelitian Hibah Internal. Universitas Respati Yogyakarta.

Agustin, Y., Indra, E.N., Afriani, Y. (2018). Asupan protein dan somatotype pada atlet pencak silat di Pembinaan Atlet Berbakat Yogyakarta. Ilmu Gizi Indonesia, 01 (02): 120-126.

Arsani, N.L.K.A., Agustini, N.N.M., Sudarmada, I.N. (2014). Manajemen Gizi Atlet Cabang Olahraga Unggulan di Kabupaten Buleleng. Jurnal Sains dan Teknologi, 3 (1): 275-287.

Cahyono, M.E., Nurhayati, F. (2014). Profil Tingkat Kecukupan Energi Siswa pada Ekstrakurikuler Pencak Silat di SMA Negeri 1 Nganjuk. Jurnal Pendidikan Olahraga dan Kesehatan, 02 (03): 550 $-553$. 
Chandradewi, AASP., Irianto. (2017). Asupan Energi, Protein, dan Stamina Atlet di Pusat Pendidikan Dan Latihan Olahraga Pelajar Nusa Tenggara Barat. Jurnal Kesehatan Prima, 11 (1): 28-35.

Departemen Kesehatan RI. (2007). Pedoman Penyelenggaraan Makanan Rumah Sakit. Jakarta: Direktorat Bina Pelayanan Medik Dasar, Direktorat Jenderal Bina Pelayanan Medik.

Faizal, A., Hadi, F.K. (2019). Gambaran Faktor-Faktor Penyebab Masalah Berat Badan (Overweight) Atlet Pencak Silat pada Masa Kompetisi. Jurnal Ilmiah Sport Coaching and Education, 1: 65-78.

Hariono, Awan. (2006). Metode Melatih Fisik Pencak Silat. FIK UNY. Yogyakarta

Hasbullah, U.H.A., Setiyowati, E., Widiatmi, N., Dzulqarnaen, F.F., Noor, Z., Aminah, S. (2017). Sistem Penyelenggaraan dan Pengelolaan Makanan bagi Atlet Sepak Bola. Jendela Olahraga, 2 (1): 148-154.
Irawan, M. A. (2007). Nutrisi, Energi, dan Performa Olahraga, 01 (04). Polton Sport Science \& Performance Lab.

Irianto, D.P. (2007). Panduan Gizi Lengkap Keluarga dan Olahragawan. PT Andi. Yogyakarta.

Kandarina BI. (2007). Sports Nutrition. Short Course Gizi dan Olahraga April 13-14. Magister Gizi Kesehatan FKUGM.

Kementerian Kesehatan RI. (2014). Pedoman Gizi Olahraga Prestasi. Jakarta: Direktorat Jenderal Bina Gizi dan Kesehata Ibu dan Anak.

Kuswari, M., Handayani, F., Gifari, N., \& Nuzrina, R. (2019). Relationship of Energy Intake, Macro and Micro Nutrients to Physical Fitness of Athletes of Dyva Taekwondo Centre Cibinong. JUARA: Jurnal Olahraga, 5(1), 19-30. https://doi.org/10.33222/juara.v5i1.57 2

Nurdianty, I., Radhiyah, N., Dachlan, D.M., Nawir, N. (2012). Penyelenggaraan Makanan dan Tingkat Kepuasan Atlet 
di Pusat Pendidikan dan Latihan Pelajar Dinas Pendidikan Pemuda dan Olahraga Makassar. Media Gizi Masyarakat Indonesia. 1 (2): 91-96.

Paiman. (2010). Pengaruh gizi terhadap prestasi olahraga pencak silat. Prosiding Seminar Nasional III. Yogyakarta, 104-251.

Purba MB. 2007. Pengaruh Kebiasaan Makan terhadap Prestasi Atlet. Short Course Nutrition and Sport; April 1314. Magister Gizi Kesehatan FKUGM.

Rachmawati, I., Rahmawati, N.T., Penggalih, M.H.S.T., Kandarina, B.J.I. (2014). Identification of Hydration Status with Urine Profile Measurement and Drink Consumption in Pencak Silat Athlete in Yogyakarta State University. Prosiding International Seminar of Sport Culture and Achievement. FIK UNY.

Rotua, M. dan Siregar, R. (2015). Manajemen Sistem Penyelenggaraan Makanan Institusi Dasar. Penerbit Buku Kedokteran ECG, Jakarta.
Sutyawan, Setiawan, B. (2013). Penyelenggaraan Makanan, Daya Terima Makanan, dan Tingkat Asupan Siswa Asrama Kelas Unggulan SMA 1 Pemali Bangka Belitung. Jurnal Gizi dan Pangan, 8(3): 207-214.

Ulfa, N.A., Widajanti, L., Suyatno. (2017). Perbedaan Status Gizi, Tingkat Konsumsi Gizi, Aktivitas Fisik dan Kebugaran Jasmani (Studi pada Siswa yang Mengikuti Ekstrakurikuler Pencak Silat dan Futsal di Sekolah Menengah Kejuruan Teuku Umar Kota Semarang Tahun 2017. Jurnal Kesehatan Masyarakat (e-Journal), 5 (4): 714-721.

Widiastuti, P.A., Kushartanti, B.M.W., Kandarina, B.J.I, (2009). Pola makan dan kebugaran jasmani atlet pencak silat selama pelatihan daerah Pekan Olahraga Nasional XVII Provinsi Bali tahun 2008. Jurnal Gizi Klinik Indonesia, 6 (1): 13-20.

Woro, O. (2005). Sistem Pengelolaan Makanan di Tempat Pemusatan Latihan Atlet. Jurnal Kesehatan Masyarakat, 1 (1): 8-13. 
Wulandari TS. (2004). Pengaruh Asrama Atlet Sepakbola terhadap Status Gizi (IndeksMassa Tubuh, Kadar Hemoglobin), Aktivitas Fisik, dan Kesegaran Jasmani.Skripsi. Universitas Diponogoro.

Yanti, S.A.P.E., Ambartana, I.W., Dewantari, N.M. (2018). Pola Konsumsi Sayur dan Buah, Kebiasaan Olahraga dan Status Gizi Anggota Persatuan Pencak Silat Ranting Bayad Desa Bayad Tegallalang Gianyar. Jurnal Ilmu Gizi: Journal of Nutrition Science, 7 (3): 115-121. 